International Journal of

Environmental Research and

Public Health

ISSN 1660-4601

Article

www.mdpi.com/journal/ijerph

\title{
Arsenic in Soils and Forages from Poultry Litter-Amended Pastures
}

\author{
Shadi Ashjaei, William P. Miller *, Miguel L. Cabrera and Sayed M. Hassan
}

Department of Crop and Soil Sciences, The University of Georgia, 3111 Miller Plant Sciences

Building, Athens, GA 30602, USA; E-Mails: sashjaei@uga.edu (S.A.); mcabrera@uga.edu (M.L.C.); shassan@uga.edu (S.M.H.)

* Author to whom correspondence should be addressed; E-Mail: wmiller@uga.edu; Tel. +1-706-542-2461; Fax: +1-706-542-0914.

Received: 1 March 2011; in revised form: 23 April 2011 / Accepted: 28 April 2011 /

Published: 12 May 2011

\begin{abstract}
In regions of concentrated poultry production, poultry litter (PL) that contains significant quantities of trace elements is commonly surface-applied to pastures at high levels over multiple years. This study examined the effect of long-term applications of PL on soil concentrations of arsenic (As), copper $(\mathrm{Cu})$, Zinc $(\mathrm{Zn})$, and the uptake of these elements by bermuda grass grown on Cecil (well-drained) and Sedgefield (somewhat poorly-drained) soils. The results showed that concentrations of $\mathrm{As}, \mathrm{Cu}$, and $\mathrm{Zn}$ in soils that had received surface-applied PL over a 14-year period were significantly greater than untreated soil at $0-2.5$ and $2.5-7.5 \mathrm{~cm}$ depths. However, the levels were well below the USEPA loading limits established for municipal biosolids. Arsenic fractionation showed that concentrations of all As fractions were significantly greater in PL-amended soils compared to untreated soils at $0-2.5$ and $2.5-7.5 \mathrm{~cm}$ depths. The residual fraction was the predominant form of $\mathrm{As}$ in all soils. The water-soluble and $\mathrm{NaHCO}_{3}$-associated As were only $2 \%$ of the total As. Significant differences were found in concentrations of these trace elements and phosphorus (P) in forage from PL-amended soils compared to that in untreated plots. The concentrations of $\mathrm{Cu}, \mathrm{Zn}$, As, and $\mathrm{P}$ were significantly greater in forage from Sedgefield amended soil compared to Cecil soil, but were in all cases below levels of environmental concern.
\end{abstract}

Keywords: poultry litter; fractionation; sodium bicarbonate; residual; water-soluble 


\section{Introduction}

The poultry industry is an important component of agricultural production in Georgia and the other parts of the United States. Poultry litter (PL) is commonly surface-applied to pastures and is considered a valuable source of $\mathrm{N}, \mathrm{P}$, and $\mathrm{K}$. It also contains high concentrations of trace elements such as arsenic (As), copper $(\mathrm{Cu})$, and zinc $(\mathrm{Zn})$ as a result of their use as growth promoters in poultry feed. Arsenic occurs in PL as a result of the use of organoarsenical compounds such as roxarsone (ROX, 3-nitro-4-hydroxyphenyl-arsenic acid) as a feed additive at concentrations of 25 to $50 \mathrm{mg} \mathrm{kg}^{-1}$ for prevention of fungal disease and for weight gain improvement [1]. Georgia is one of the top broiler chicken producing regions in the United States and due to transport costs, most PL is applied to fields within short distances of poultry houses. Every broiler produces between 1.46 and $2.67 \mathrm{~kg}$ of waste over its life span [2,3]. Repeated surface applications of PL could result in accumulation of heavy elements at shallow soil depth due to the immobility of these elements and result in environmental problems. Guptal and Charles [4] reported greater concentrations of $\mathrm{As}, \mathrm{Cd}, \mathrm{Cu}$, and $\mathrm{Mn}$ in fields that had received long-term PL applications compared to unamended soil. Several studies have shown that long-term PL application has an effect on elevation of trace elements (e.g., As, $\mathrm{Cu}$, and $\mathrm{Zn}$ ) especially at the soil surface [4-8]. A study of the long-term effects of broiler litter applications on $\mathrm{Cu}$ and $\mathrm{Zn}$ in Maryland Coastal Plain soil showed higher concentrations of these trace elements in PL-amended soil compared to a wooded area [9].

Land application of PL is regulated based on applying $\mathrm{N}$ and/or $\mathrm{P}$ for crop needs. There are no regulatory standards for trace elements concentrations or loading. In the United States, only municipal biosolids have regulatory limits on trace metals. The USEPA 503 regulation loading limits for As, $\mathrm{Cu}$, and $\mathrm{Zn}$ in soil amended with biosolids are 20,750, and 1,400 $\mathrm{mg} \mathrm{kg}^{-1}$, respectively [10,11]. These standards are often used as a reference for other land-applied wastes.

Arsenic in soils is distributed among various forms which are associated with different soil constituents. Arsenic fractionation in different soil solid phases can be examined by selective sequential extraction with reagents of increasing dissolution strength. Based on the chemical similarity of $\mathrm{P}$ and As, modified versions of $\mathrm{P}$ fractionation methods have been adapted for As [12-16] These schemes differ in their sequential extraction steps, reagents, and extraction conditions. A common feature among most methods is extracting with $\mathrm{NH}_{4} \mathrm{Cl}$ or $\mathrm{H}_{2} \mathrm{O}$ (water-soluble As), $\mathrm{NaHCO}_{3}$ (surface-adsorbed $\mathrm{As}$ ), $\mathrm{NaOH}$ (bound to $\mathrm{Fe}$ oxide), $\mathrm{NH}_{4} \mathrm{~F}$ (bound to $\mathrm{Al}$ oxide) and the residual phase (acid digest). The results of As fractionation aid in understanding the distribution of As among different soil constituents and help in predicting its mobility and bioavailability. In general, the water-soluble form is considered as readily bioavailable and is presumably susceptible to runoff losses compared to more tightly bound forms. A study of As distribution in PL and long-term PL amended soil (upper coastal plain, MS) that had received PL at a rate of $10 \mathrm{Mg} \mathrm{ha}^{-1}$ for 25 years showed that $47 \%$ of As in PL was water-soluble fraction. However, $72 \%$ of As in PL-amended soils was in the residual fraction and was considered as the least susceptible to runoff losses or downward movement. It was concluded that immediately after PL application there would be a high risk of mobilization of As from top soil, but over time the water-soluble form of As converts to more stable fractions with less susceptibility to be lost by runoff [17]. 
The objectives of this study were: (1) to estimate the potential environmental concern associated with $\mathrm{As}, \mathrm{Cu}$, and $\mathrm{Zn}$ in long-term PL-amended pastures; (2) to assess the distribution of different forms of As fractions in PL-amended pastures and (3), to determine forage uptake of $\mathrm{As}, \mathrm{Cu}, \mathrm{Zn}$, and $\mathrm{P}$ in PL-amended pastures. Two southern piedmont soils (well-drained Cecil series and somewhat poorly-drained Sedgefield) were compared in the experiments.

\section{Materials and Methods}

\subsection{Soil Sampling and Characterization}

This research was conducted on six 0.8 ha PL-amended and two control plots with tall fescue (Festuca arundinacea Scherb) and bermuda grass (Cynodon dactylon L.), located at the College of Agricultural and Environmental Sciences Central Georgia Research and Education Center near Eatonton, GA $\left(39^{\circ} 24^{\prime} \mathrm{N}, 83^{\circ} 29^{\prime} \mathrm{W}\right.$, elevation $\left.150 \mathrm{~m}\right)$. The soil series comprising the plots include Cecil (fine, kaolinitic, thermic Typic Kanhapludults) and Sedgefield (fine, mixed, active, thermic Aquic Hapludults). Poultry litter had been applied annually to each amended plot since 1995 at $5 \mathrm{Mg} \mathrm{ha}^{-1}$ and was applied on April 2008, November 2008, and March 2009 during this experiment. Four PL-amended plots contained predominately Cecil soil, two PL-amended plots contained predominately Sedgefield soil and two unamended (control) plots were largely Cecil soil. Composite soil sampling was conducted in June 2008 two months after PL application with six replicate samples taken from PL-amended plots containing Cecil and Sedgefield soils and 3 replicate samples from control plots (each replicate was a composite of 12 soil subsamples) at 0-2.5 and 2.5-7.5 cm depths. The samples were air-dried and passed through 2-mm sieve, mixed, and stored at room temperature before analysis. Soil particle-size distribution was determined by the micropipette method [18]. Sodium dithionite was used to dissolve total free iron oxide and Tamm's reagent was used to remove amorphous iron oxide in both PL-amended soils, and Fe was determined by atomic absorption spectrometer [19]. Total carbon was determined on composite samples by dry combustion (Leco CNS analyzer). A 1:1 soil-to-water mixture was used to determine soil $\mathrm{pH}$.

\subsection{Forage Sampling}

Forage from these experimental plots was sampled twice in October 2008, five months after PL application, and in June 2009, three months after PL application. The pastures were predominantly bermuda grass (Cynodon dactylon L.) and tall fescue (Festuca arundinacea Scherb). Forage samples were taken from two PL-amended plots containing Cecil soil, two PL-amended plots containing Sedgefield soil, and two control plots (containing Cecil soil) with three replicate samples per each plot. Each replicate was a composite sample of 10-12 randomly selected areas of bermuda grass which were clipped manually. The grass was in its vegetative stage approximately $20-30 \mathrm{~cm}$ tall, of which the top 10-15 cm was sampled. The samples were oven-dried at $65{ }^{\circ} \mathrm{C}$ for $48 \mathrm{hr}$ and ground prior to analysis. 


\subsection{Arsenic Fractionation}

Soils were extracted sequentially to determine distinct fractions of soil As using a method described by Shiowatana et al. [16]. Soil As pools extracted consist of: (1) water-soluble As (0.01 $\left.\mathrm{M} \mathrm{Ca}\left(\mathrm{NO}_{3}\right)_{2}\right)$; (2) surface-adsorbed As (0.5 $\left.M \mathrm{NaHCO}_{3}\right)$; (3) Fe- and Al-associated As (0.1 $\left.M \mathrm{NaOH}\right)$; and (4) residual As [16]. In the As fractionation, $1 \mathrm{~g}$ of air-dried soil was extracted with $30 \mathrm{~mL}$ of $0.01 \mathrm{M} \mathrm{Ca}\left(\mathrm{NO}_{3}\right)_{2}$ in $30 \mathrm{~mL}$ polypropylene high speed centrifuge tubes, shaken for $16 \mathrm{~h}$ and centrifuged at 3,000 rpm for $15 \mathrm{~min}$. The supernatant solution was filtered with Whatman No. 42 filter paper. The soil residue was resuspended with $30 \mathrm{~mL} \mathrm{NaHCO}$ and shaken for $16 \mathrm{hr}$, centrifuged as in step 1 and filtered with Whatman No.42 filter paper. The solution was diluted 4-fold prior to analysis in order to run the samples by ICP-MS (Inductively Coupled Plasma Mass Spectrometry, Perkin Elmer Model Elan 9000). In the last step, the soil residue from step 2 was resuspended with $30 \mathrm{~mL}(0.1 \mathrm{M})$ $\mathrm{NaOH}$ for $16 \mathrm{hr}$, centrifuged as in previous steps and filtered with Whatman No.42 filter paper and diluted 10 -fold prior to analysis by ICP-MS. The residual arsenic was calculated by subtracting the sum of all As fractions from total As in soil. The water-soluble As concentrations in PL were determined by extraction of $1 \mathrm{~g}$ freeze-dried PL with $10 \mathrm{~mL}$ distilled water in $50 \mathrm{~mL}$ polypropylene centrifuge tubes. After shaking for $2 \mathrm{~h}$, the extracts were centrifuged at 15,000 rpm for 15 minutes, filtered $(0.45 \mu \mathrm{m})$, and diluted 20 -fold with distilled water prior to analysis by ICP-MS [20].

\subsection{Total Trace Elements Analysis}

Total trace elements in PL-amended soil were determined using the USEPA SW-846 hot plate acid digestion method 3050B [21]. An air-dried soil sample $(0.5 \mathrm{~g})$ was transferred to a $250 \mathrm{~mL}$ glass Erlenmeyer flask and was covered with a small glass funnel to reflux vapors and placed on a hot plate under a fume hood. Ten $\mathrm{mL}$ of $70 \% \mathrm{HNO}_{3}$ was added to the flask and heated to boiling for about 3 hrs. In order to complete the digestion, $0.5 \mathrm{~mL}$ hydrogen peroxide $\left(\mathrm{H}_{2} \mathrm{O}_{2}\right)$ was added slowly to the flasks after cooling. This addition was repeated until a clear solution was obtained. After cooling, flasks were taken to $100 \mathrm{~mL}$ final volume gravimetrically using deionized water and left overnight for settling of particulates. The decanted solutions were stored in polyethylene plastic vials and diluted at a 1:10 ratio prior to analysis by ICP-MS for $\mathrm{As}, \mathrm{Cu}$, and $\mathrm{Zn}$. Replicates, blanks, calibration verification, and standard reference material (SRM-2709) were analyzed to ascertain data quality.

Poultry litter samples were freeze-dried (LabConco Lyph. Lock 6, Kansas, MO) and total As, Cu, and $\mathrm{Zn}$ in PL was analyzed using a microwave acid digest method USEPA 3051A [22]. All microwave vessels were soaked in $5 \% \mathrm{HNO}_{3}$ overnight and cleaned by microwaving with $2 \mathrm{~mL} \mathrm{HNO}_{3}$ and $10 \mathrm{~mL}$ distilled water (CEM corporation, Model 81D) for 20 minutes prior to use for sample digestion. The $0.12 \mathrm{~g}$ freeze-dried PL samples were transferred to microwave vessels and $5 \mathrm{~mL} \mathrm{70 \%} \mathrm{HNO}_{3}$ was added. Vessels were weighted before and after digestion to assure negligible solution loss during digestion. After removing from the microwave, vessels were cooled to room temperature and $25 \mathrm{~mL}$ distilled water was added to all vessels. The final samples were stored in polyethylene vials prior to analysis by ICP-MS. Trace elements (As, $\mathrm{Cu}$, and $\mathrm{Zn}$ ) and phosphorus concentrations in forage were determined by the same method using $0.1 \mathrm{~g}$ oven-dried forage samples. 


\subsection{Mehlich-I (Double Acid) Extractable Cu and Zn}

Extractable $\mathrm{Cu}$ and $\mathrm{Zn}$ in soils at two depths $(0-2.5,2.5-7.5 \mathrm{~cm})$ were measured by the Mehlich-I method. The Mehlich-I extraction solution consists of $0.05 \mathrm{M} \mathrm{HCl}$ and $0.0125 \mathrm{M} \mathrm{H}_{2} \mathrm{SO}_{4}$ which was prepared by adding $4.17 \mathrm{~mL}$ of concentrated $\mathrm{HCl}(12 \mathrm{M})$ and $0.70 \mathrm{~mL}$ of concentrated $\mathrm{H}_{2} \mathrm{SO}_{4}(17.8 \mathrm{M})$ and brought to volume in a 1 litter volumetric flask. Five $\mathrm{g}$ of air-dried soil along with $20 \mathrm{~mL}$ of Mehlich-I extraction solution was transferred to $50 \mathrm{~mL}$ polypropylene centrifuge tubes and shaken for $5 \mathrm{~min}$ [23]. The solution was filtered through Whatman No.42 filter paper. The filtered samples were diluted 1:100 prior to analysis by ICP-MS.

\subsection{Statistical Analysis}

The experimental design was a one-way analysis (treated vs. control) with unequal replication and repeated measures. Arsenic fractionation in control and PL-amended soils at 0-2.5 and 2.5-7.5 cm depths were examined using the PROC GLM procedure [24]. The main effect of treatment (control (Cecil) and PL-amended Cecil and Sedgefield soils) on concentrations of trace elements in forage tissue was significant at $p<0.0001$ and means were separated using LSMEANS procedure with PDIFF option. Mean concentration of trace elements in forage tissue were examined using the PROC MIXED procedure and means were separated using LSMEANS procedure with PDIFF option.

\section{Results and Discussion}

\subsection{Total Trace Elements in Soils}

Total concentrations of $\mathrm{As}, \mathrm{Cu}$, and $\mathrm{Zn}$ in PL applied to the pasture on April 2008, November 2008, and March 2009 varied with the specific application (Table 1). These variations are due to differences in composition of poultry feeds and PL management practices. Trace element concentrations of $\mathrm{As}, \mathrm{Cu}$ and $\mathrm{Zn}$ were low in all PL samples compared to pollutant limit metal concentrations for land application of biosolids (41 $\mathrm{mg} \mathrm{As} \mathrm{kg}^{-1}, 1,500 \mathrm{mg} \mathrm{Cu} \mathrm{kg}^{-1}$, and 2,800 $\mathrm{mg} \mathrm{Zn} \mathrm{kg}^{-1}$ ) [10].

Table 1. Total concentrations $\left(\mathrm{mg} \mathrm{kg}^{-1}\right)$ of trace elements in poultry litter applied on April 2008, November 2009, and March 2009.

\begin{tabular}{lccc}
\hline & As & Cu & Zn \\
\hline April 2008 & 23.6 & 207 & 229 \\
November 2008 & 14.9 & 743 & 431 \\
March 2009 & 26.7 & 672 & 671 \\
\hline
\end{tabular}

Table 2 shows the physical and chemical properties of both PL-amended soils. The clay content and total amounts of $\mathrm{Fe}$ oxide of amended Cecil soil were greater at both depths compared to those of Sedgefield soil. Hence, it may be presumed that higher Fe content of Cecil soil will increase the soil As retention capacity. Sarkar et al. [25] reported that soils with higher concentrations of amorphous Fe/Al oxides retain more As and thus reduce its bioavailability. Rutherford et al. [26] found a strong correlation between acid-extractable Fe and As content of PL-amended soils, suggesting adsorption of As with Fe oxides. 
Table 2. General chemical and physical properties of Cecil and Sedgefield PL-amended soils at $0-2.5$ and $2.5-7.5 \mathrm{~cm}$ depths.

\begin{tabular}{|c|c|c|c|c|c|c|c|c|}
\hline \multirow{2}{*}{ Soil } & \multirow{2}{*}{$\begin{array}{l}\text { Depth } \\
\text { (cm) }\end{array}$} & \multirow{2}{*}{$\begin{array}{c}\mathrm{pH} \\
(1: 1 \text { water })\end{array}$} & \multicolumn{3}{|c|}{$\begin{array}{c}\text { Composition } \\
\left(\mathrm{mg} \mathrm{kg}^{-1}\right)\end{array}$} & \multicolumn{3}{|c|}{$\begin{array}{c}\text { Particle size } \\
\text { distribution (\%) }\end{array}$} \\
\hline & & & $\begin{array}{c}\text { Total Fe } \\
\text { Oxide }\end{array}$ & $\begin{array}{c}\text { Amorphous } \\
\text { Fe Oxide }\end{array}$ & $\begin{array}{c}\text { Total } \\
\text { C }\end{array}$ & Sand & Silt & Clay \\
\hline Cecil & $0-2.5$ & 6.00 & 7,173 & 3,397 & 57.4 & 58 & 34 & 8 \\
\hline Cecil & $2.5-7.5$ & 5.87 & 7,511 & 3,356 & 26.4 & 49 & 36 & 15 \\
\hline Sedgefield & $0-2.5$ & 5.99 & 4,505 & 3,259 & 44.7 & 75 & 23 & 2 \\
\hline Sedgefield & $2.5-7.5$ & 5.85 & 5,281 & 3,936 & 20.8 & 72 & 25 & 3 \\
\hline
\end{tabular}

There were differences in total concentrations of $\mathrm{As}, \mathrm{Cu}$, and $\mathrm{Zn}$ in PL-amended soils compared to those in control plot at $0-2.5 \mathrm{~cm}$ and $2.5-7.5 \mathrm{~cm}$ depths (Table 3). Total concentration of As was greater in PL-amended Cecil and Sedgefield soils $\left(3.67 \mathrm{mg} \mathrm{kg}^{-1}\right.$ and $3.91 \mathrm{mg} \mathrm{kg}^{-1}$ ) compared to those in control plots $\left(1.46 \mathrm{mg} \mathrm{kg}^{-1}\right)$ at $0-2.5 \mathrm{~cm}$ depth. Similar results were found for total As concentrations in both PL-amended soils compared to those in control plots at $2.5-7.5 \mathrm{~cm}$ depth. Han et al. [17] also found significant amounts of As in PL-amended soils with a long-term history of PL application (25 years) compared to unamended soil, and total As concentrations in the amended soils were three times greater than those in unamended soils $\left(8.4\right.$ vs. $\left.2.68 \mathrm{mg} \mathrm{kg}^{-1}\right)$. The concentrations of As in Cecil and Sedgefield soils were not different compared with each other at either depth. Total $\mathrm{Cu}$ and $\mathrm{Zn}$ were greater in both PL-amended soils compared to those in control plots at the $0-2.5 \mathrm{~cm}$ depth, although not at the lower depth (Table 3). Han et al. [27] reported concentrations of $\mathrm{Cu}$ and $\mathrm{Zn}$ in unamended soil $(0-10 \mathrm{~cm})$ were significantly lower $\left(2.2\right.$ and $\left.9.8 \mathrm{mg} \mathrm{kg}^{-1}\right)$ compared to PL-amended soil (74.5 and $88.8 \mathrm{mg} \mathrm{kg}^{-1}$ ). Brock et al. [28] also showed accumulation of $\mathrm{Cu}$ and $\mathrm{Zn}$ in soils with a history of 40 years of PL application in the plow layer $(0-17.5 \mathrm{~cm})$. The total $\mathrm{Cu}$ concentrations ranged from 5.9 to $30.1 \mathrm{mg} \mathrm{Cu} \mathrm{kg}^{-1}$ soil, and total concentrations of $\mathrm{Zn}$ were up to $112 \mathrm{mg} \mathrm{Zn} \mathrm{kg}{ }^{-1}$ soil. Other studies reported elevation of $\mathrm{Cu}$ and $\mathrm{Zn}$ concentration in the top 5-10 cm depth in short and long-term application of PL [27,29]. Litter applications for 15 to $25 \mathrm{yr}$ resulted in accumulation of $\mathrm{Cu}$ and $\mathrm{Zn}$ to a depth of $40 \mathrm{~cm}$ compared with unamended soil [5].

The observed distribution of trace elements is clearly due to the surface application of the PL and lack of incorporation into the A horizon. However, concentrations of trace elements were well below USEPA loading limits at both depths. For an application rate of $5 \mathrm{Mg} \mathrm{ha}^{-1}$ per year with an average As concentration of $20 \mathrm{mg} \mathrm{kg}^{-1}$ in PL applied on the soil surface, the average As input rate was approximately $0.1 \mathrm{~kg} \mathrm{As} \mathrm{ha}^{-1} \mathrm{yr}^{-1}$. This annual As loading rate is below the annual ceiling rate (2.0 kg As ha $\mathrm{yr}^{-1}$ ) for safe land application of biosolids [10]. The same estimation can be done for $\mathrm{Cu}$ and $\mathrm{Zn}$ with average concentrations of $500 \mathrm{mg} \mathrm{Cu} \mathrm{kg}^{-1}$ and $400 \mathrm{mg} \mathrm{Zn} \mathrm{kg}^{-1}$ in PL applied at a rate of $5 \mathrm{Mg} \mathrm{ha}^{-1}$ per year. The $\mathrm{Cu}$ and $\mathrm{Zn}$ input rates were approximately $2.5 \mathrm{~kg} \mathrm{Cu} \mathrm{ha}^{-1} \mathrm{yr}^{-1}$ and $2.0 \mathrm{~kg} \mathrm{Zn} \mathrm{ha}{ }^{-1} \mathrm{yr}^{-1}$ which are below the annual ceiling rates $\left(75 \mathrm{~kg} \mathrm{Cu} \mathrm{ha}^{-1} \mathrm{yr}^{-1}\right.$ and $\left.140 \mathrm{~kg} \mathrm{Zn} \mathrm{ha}^{-1} \mathrm{yr}^{-1}\right)$ for safe land application of biosolids. 
Table 3. Total concentrations $\left(\mathrm{mg} \mathrm{kg}^{-1}\right)$ of $\mathrm{As}, \mathrm{Cu}$, and $\mathrm{Zn}$ in poultry litter-amended pastures and control plot.

\begin{tabular}{llll}
\hline & As & Cu & Zn \\
\hline Depth $(0-2.5 \mathrm{~cm})$ & & & \\
\hline Control & $1.46 \mathrm{a}^{\mathrm{a}}$ & $13.6 \mathrm{a}$ & $32.0 \mathrm{a}$ \\
Cecil (PL-amended) & $3.67 \mathrm{~b}$ & $95.6 \mathrm{~b}$ & $121 \mathrm{~b}$ \\
Sedgefield (PL-amended) & $3.91 \mathrm{~b}$ & $88.2 \mathrm{~b}$ & $88.0 \mathrm{c}$ \\
\hline Depth $(2.5-7.5 \mathrm{~cm})$ & & & $34.0 \mathrm{a}$ \\
\hline Control & $1.57 \mathrm{a}^{\mathrm{a}}$ & $29.3 \mathrm{a}$ & $51.6 \mathrm{a}$ \\
Cecil (PL-amended) & $3.04 \mathrm{~b}$ & $44.1 \mathrm{ab}$ & $56.0 \mathrm{a}$ \\
Sedgefield (PL-amended) & $3.46 \mathrm{~b}$ & $66.5 \mathrm{c}$ & 1,400 \\
\hline USEPA loading Limit & 20 & 750 & \\
a Means within a column at a given depth followed by the same letter are not different significantly \\
according to LSD $(p<0.05)$
\end{tabular}

\subsection{Sequential Extraction of As}

Sequential extraction was used here in the operational sense of assessing the solubility of As in response to increasingly harsh chemical extractants that have been correlated with specific types of As binding in soils. In the sequential extraction data, analysis of variance showed that there was a statistical difference in main effect of treatment (control and PL-amended Cecil and Sedgefield soils) for all fractions. However, only water-soluble and Fe/Al-associated As showed a significant interaction effect between treatment and depth at $p<0.05$. There were significant differences in concentrations of water-soluble As in PL-amended soils compared to control at both depths (Table 4). It was calculated that 38\%, 25\%, and 26\% of total As in PL applied in April 2008, November 2008, and March 2009 was in water-soluble form, respectively. Only $2 \%$ of total As was in water-soluble fraction two months after PL application in both soils at $0-2.5 \mathrm{~cm}$ depth. It was observed that $10 \%$ and $13 \%$ of total As was in surface adsorbed As $\left(\mathrm{NaHCO}_{3}\right)$ fraction at 0-2.5 cm depth in PL-amended Cecil and Sedgefield soils. In addition, the amount of $\mathrm{NaHCO}_{3}$-associated As was significantly greater in Sedgefield soil compared to Cecil soil only at depth of $0-2.5 \mathrm{~cm}$. Solubility of As in PL-amended soils, indicated here by water-soluble and $\mathrm{NaHCO}_{3}$-associated As, is linked to its mobility and plant uptake. The fact that long-term PL-amended Sedgefield soil has more $\mathrm{NaHCO}_{3}$-associated As suggests a greater potential loss of As via runoff into surface water systems or uptake by plants compare to that in PL-amended Cecil soil. Iron and Al-associated $\mathrm{As}(\mathrm{NaOH})$ in two PL-amended soils were significantly greater than control at both depths. There was no significant difference in concentration of Fe/Al-associated As between Cecil and Sedgefield soils, which may suggest As was associated with amorphous Fe oxides, which were present at similar levels in both soils (Table 2). The residual fraction was the major form of As with approximately $50 \%$ of total As in both amended soils. Overall, there were no significant differences in concentrations of As fractions between PL-amended soils at 0-2.5 and 2.5-7.5 cm except for $\mathrm{NaHCO}_{3}$ - associated As at 0-2.5 cm depth. Apparently, As transforms to more stable forms, resulting in decreased As bioavailability and mobility months after PL application. This may also indicate possible loss of water-soluble As via runoff shortly after PL is applied to field. 
Table 4. Arsenic fractionation $\left(\mathrm{mg} \mathrm{kg}^{-1}\right)$ in poultry litter-amended soils at $0-2.5$ and $2.5-7.5 \mathrm{~cm}$ depths.

\begin{tabular}{lcllll}
\hline & WE $^{\mathbf{a}}$ & $\mathbf{N a H C O}_{3}$ & $\mathbf{N a O H}$ & Residual & Total \\
\hline Depth $(0-2.5 \mathrm{~cm})$ & & & & & \\
\hline Control & $0.03 \mathrm{a}^{\mathrm{b}}$ & $0.17 \mathrm{a}$ & $0.55 \mathrm{a}$ & $0.55 \mathrm{a}$ & $1.29 \mathrm{a}$ \\
Cecil (PL-amended) & $0.07 \mathrm{~b}$ & $0.36 \mathrm{~b}$ & $1.43 \mathrm{~b}$ & $1.81 \mathrm{~b}$ & $3.67 \mathrm{~b}$ \\
Sedgefield (PL-amended) & $0.07 \mathrm{~b}$ & $0.53 \mathrm{c}$ & $1.52 \mathrm{~b}$ & $1.79 \mathrm{~b}$ & $3.91 \mathrm{~b}$ \\
\hline Depth (2.5-7.5 cm) & & & & & \\
\hline Control & $0.003 \mathrm{a}^{\mathrm{b}}$ & $0.07 \mathrm{a}$ & $0.81 \mathrm{a}$ & $0.50 \mathrm{a}$ & $1.39 \mathrm{a}$ \\
Cecil (PL-amended) & $0.017 \mathrm{~b}$ & $0.21 \mathrm{ab}$ & $1.09 \mathrm{~b}$ & $1.68 \mathrm{~b}$ & $3.03 \mathrm{~b}$ \\
Sedgefield (PL-amended) & $0.014 \mathrm{~b}$ & $0.24 \mathrm{~b}$ & $1.19 \mathrm{~b}$ & $2.00 \mathrm{~b}$ & $3.46 \mathrm{~b}$ \\
\hline
\end{tabular}

${ }^{a} \mathrm{WE}, \mathrm{NaHCO}$, and $\mathrm{NaOH}$ stand for water-soluble-, adsorbed-, and Fe/Al-associated arsenic, respectively; ${ }^{b}$ Means within column followed by the same letter are not different significantly according to $\operatorname{LSD}(p<0.05)$.

\subsection{Plant Uptake by Forage}

The results of statistical analysis by ANOVA of trace elements concentrations in forage tissue from PL-amended soil and control showed that there was a significant main treatment effect of $\mathrm{P}, \mathrm{Cu}, \mathrm{Zn}$, and As concentrations in forage tissues from control and PL-amended soils (Table 5). However, no significant interaction was found between treatment and date effect for any trace elements or $\mathrm{P}$ (October and June sampling). There were differences in concentrations of all trace elements in forage tissue from PL-amended soils compared to those in control plot except for amount of $\mathrm{Zn}$ in forage tissue from Cecil soil (Table 6). Another study of metal uptake by tall fescue as affected by PL application at low (5.6 $\left.\mathrm{t} \mathrm{ha}^{-1}\right)$ and high $\left(11.3 \mathrm{t} \mathrm{ha}^{-1}\right)$ rates showed that $\mathrm{Zn}$ and $\mathrm{Cu}$ uptake were significantly greater in PL-amended soil compared to the control [30]. However, Kingery et al. [5] showed that tall fescue grown in pastures with a history of long-term litter application had similar $\mathrm{Cu}$ and $\mathrm{Zn}$ concentrations as fescue grown in pastures with no history of litter application. The concentration of As in forage from Sedgefield soil was significantly greater than Cecil soil. The coarse-textured soils likely contain higher amounts of readily mobile As, while As in fine textured soils is mainly immobile due to higher content of minerals and organic constituents which are capable of binding anionic As species. There were no differences in concentrations of $\mathrm{Cu}$ and $\mathrm{Zn}$ in forage tissues from Cecil soil compared to those from Sedgefield soil.

Table 5. Analysis of variance of $\mathrm{P}, \mathrm{Cu}, \mathrm{Zn}$, and As concentrations $(\mathrm{P}>\mathrm{F})$ in bermuda grass samples from poultry litter-amended soils.

\begin{tabular}{lllll}
\hline Source & $\mathbf{P}$ & $\mathbf{C u}$ & $\mathbf{Z n}$ & As \\
\hline Treatment $^{\mathrm{a}}$ & 0.028 & 0.0012 & 0.034 & 0.003 \\
Date $^{\text {Treatment*Date }}{ }^{\mathrm{b}}$ & 0.26 & 0.0003 & 0.045 & 0.75 \\
& 0.95 & 0.25 & 0.76 & 0.79 \\
\hline
\end{tabular}

${ }^{a}$ Main treatment effect (forage samples grown on control (Cecil) and PL-amended Cecil and Sedgefield soils) significant at $p<0.05 ;{ }^{\mathrm{b}}$ Treatment by date interaction (significant at $p<0.05$ ). 
Table 6. Concentrations of elements $\left(\mathrm{mg} \mathrm{kg}^{-1}\right)$ in bermuda grass tissue from control and poultry litter-amended soils.

\begin{tabular}{lllll} 
& P & Cu & Zn & As \\
\hline Control & $2,189 \mathrm{a}^{\mathrm{a}}$ & $5.10 \mathrm{a}$ & $25.7 \mathrm{a}$ & $0.16 \mathrm{a}$ \\
Cecil (PL-amended) & $2,746 \mathrm{~b}$ & $7.05 \mathrm{~b}$ & $34.2 \mathrm{ab}$ & $0.23 \mathrm{~b}$ \\
Sedgefield (PL-amended) & $2,927 \mathrm{~b}$ & $7.23 \mathrm{~b}$ & $41.3 \mathrm{~b}$ & $0.31 \mathrm{c}$ \\
\hline
\end{tabular}

${ }^{a}$ Means within a column followed by the same letter are not different significantly according to $\operatorname{LSD}(p<0.05)$.

The concentrations of $\mathrm{Cu}$ and $\mathrm{Zn}$ in the forage samples did not exceed critical phytotoxic levels reported by Macnicol and Beckett [31] (21-40, and 210-560 mg kg ${ }^{-1}$ for $\mathrm{Cu}$, and $\mathrm{Zn}$, respectively). Long-term PL application did not produce tissue $\mathrm{Cu}$ and $\mathrm{Zn}$ levels above the NRC (National Research Council) maximum tolerance level of $\mathrm{Cu}$ for cattle (40 $\mathrm{mg} \mathrm{Cu} \mathrm{kg}^{-1}$ feed) or for sheep (15 mg Cu kg${ }^{-1}$ feed); similarly, $\mathrm{Zn}$ was well below maximum levels for cattle (500 $\mathrm{mg} \mathrm{Zn} \mathrm{kg}^{-1}$ feed) and sheep (300 $\mathrm{mg} \mathrm{Zn} \mathrm{kg}^{-1}$ feed) [32]. The forage samples from all soils were in fact $\mathrm{Cu}$ deficient for animal feed based on the minimum recommended $\mathrm{Cu}$ concentration for cattle rations of $9 \mathrm{mg} \mathrm{Cu} \mathrm{kg}{ }^{-1}$ [33]. Soon et al. [34] reported small increases in the $\mathrm{Cu}$ content of corn grain and bermudagrass grown in soil amended with sewage sludge applications $\left(31 \mathrm{~kg} \mathrm{Cu} \mathrm{ha}^{-1}\right)$ for five consecutive years.

The minimum recommended $\mathrm{Zn}$ content in cattle rations average $35 \mathrm{mg} \mathrm{kg}^{-1}$; forage samples from both PL-amended soils were close to that amount and considered Zn-sufficient for animal feed. Warman and Termeer [35] found that $\mathrm{Zn}$ content of grass forage and corn tissues grown in soil amended with sewage wastes for two consecutive years (applied twice a year) were below the $35 \mathrm{mg} \mathrm{kg}^{-1}$ minimum $\mathrm{Zn}$ requirement for cattle. The maximum tolerance levels of As for cattle and

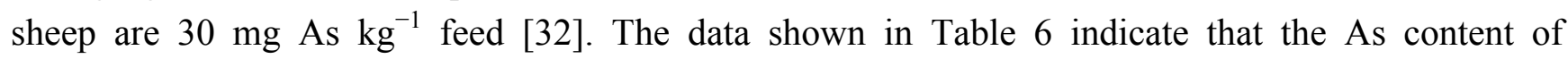
bermudagrass tissues grown in both PL-amended soils are below that amount. Since only a small fraction of total As was in the water-soluble fraction in PL-amended soils, PL had minor effect on elevation of total As in forage.

The result of Mehlich-I extraction, which is used to assess potentially plant available $\mathrm{Zn}$ in soil testing, showed greater concentrations of $\mathrm{Cu}$ and $\mathrm{Zn}$ in PL-amended Cecil and Sedgefield soils compared to those in control plot at both depths (Table7). Concentrations of extractable Zn were greater in PL-amended Sedgefield and Cecil soils (47.4 and $47.5 \mathrm{mg} \mathrm{kg}^{-1}$ ) at $0-2.5 \mathrm{~cm}$ compared to those in $2.5-7.5 \mathrm{~cm}$ depth (10.45 and $\left.11.29 \mathrm{mg} \mathrm{kg}^{-1}\right)$. Only $\mathrm{Cu}$ concentrations were greater in PL-amended Sedgefield soil at $0-2.5 \mathrm{~cm}\left(6.60 \mathrm{mg} \mathrm{kg}^{-1}\right)$ compared to that in $2.5-7.5 \mathrm{~cm}$ depth $\left(4.60 \mathrm{mg} \mathrm{kg}{ }^{-1}\right)$ at $p<0.01$. The fact that concentrations of extractable $\mathrm{Cu}$ and $\mathrm{Zn}$ were greater in PL-amended soils compared to those in control plot appear to be linked with the greater amounts of $\mathrm{Cu}$ and $\mathrm{Zn}$ in bermudagrass tissue from PL-amended soils and compared to that from control plots. However, soil test $\mathrm{Zn}$ and $\mathrm{Cu}$ increased much more than tissue levels with PL amendment. Zhou et al. [36] reported significant linear correlation between extractable soil $\mathrm{Zn}$ (and $\mathrm{Cu}$ ) concentrations extracted by $1.0 \mathrm{MNH}_{4} \mathrm{NO}_{3}$ and $\mathrm{Zn}$ (and $\mathrm{Cu}$ ) concentrations in radish tissues. Warman and Termeer [35] found that only Mehlich-I Cu was highly correlated with forage tissue $\mathrm{Cu}(r=0.98)$, and the correlation coefficients for extractable $\mathrm{Zn}$ and $\mathrm{Zn}$ uptake were not significant in soil with biosolids applications. 
Table 7. Mehlich-I extractable $\mathrm{Cu}$ and $\mathrm{Zn}\left(\mathrm{mg} \mathrm{kg}^{-1}\right)$ in control and poultry litter-amended soils.

\begin{tabular}{llc}
\hline & Cu & Zn \\
\hline Depth (0-2.5 cm) & & \\
\hline Control & $0.54 \mathrm{a}^{\mathrm{a}}$ & $6.56 \mathrm{a}$ \\
Cecil (PL-amended) & $3.71 \mathrm{~b}$ & $47.4 \mathrm{~b}$ \\
Sedgefield (PL-amended) & $6.60 \mathrm{c}$ & $47.5 \mathrm{~b}$ \\
\hline Depth $(2.5-7.5 \mathrm{~cm})$ & & \\
\hline Control & $0.98 \mathrm{a}^{\mathrm{a}}$ & $3.14 \mathrm{a}$ \\
Cecil (PL-amended) & $3.70 \mathrm{~b}$ & $11.29 \mathrm{~b}$ \\
Sedgefield (PL-amended) & $4.60 \mathrm{~b}$ & $10.45 \mathrm{~b}$ \\
\hline
\end{tabular}

${ }^{a}$ Means within a column in a given depth followed by the same letter are not different significantly according to $\operatorname{LSD}(p<0.05)$.

\section{Conclusions}

Total concentrations of $\mathrm{As}, \mathrm{Cu}$, and $\mathrm{Zn}$ in soils that had received long-term surface-applied PL were significantly greater than in unamended soil. If the USEPA annual loading limits are used as a frame of reference for serious environmental hazard, the concentrations were well below those limits. Arsenic fractionation showed concentrations of all As fractions were significantly greater in PL-amended soils compared to controls at $0-2.5$ and $2.5-7.5 \mathrm{~cm}$ depths. However, there were no significant differences in concentrations of any As fractions between two PL-amended soils at either depth except for $\mathrm{NaHCO}_{3}$-associated As at 0-2.5 cm depth. The greater amounts of $\mathrm{NaHCO}_{3}$-associated As seen in the somewhat poorly-drained Sedgefield soils amended with PL suggests greater potential loss of As via runoff or uptake by plants for these soils compared to PL-amended Cecil soils. Arsenic in the PL-amended soils was dominantly found in the residual fraction which is the least susceptible fraction to runoff losses as soluble As or downward movement.

There were greater concentrations of $\mathrm{As}, \mathrm{Cu}, \mathrm{Zn}$, and $\mathrm{P}$ in forage from PL-amended soils compared to those from control. Although PL application resulted in elevated concentrations of $\mathrm{As}, \mathrm{Cu}, \mathrm{Z}$, and $\mathrm{P}$ in forage tissues, it did not cause tissue $\mathrm{As}, \mathrm{Cu}$, and $\mathrm{Zn}$ levels to increase above the NRC domestic animal mineral tolerance levels. The forage samples from both PL-amended soils were $\mathrm{Zn}$ sufficient and $\mathrm{Cu}$ deficient for animal feed.

\section{References}

1. Jones, F.T. A broad view of arsenic. Poult. Sci. 2007, 86, 2-14.

2. Nachman, K.E.; Graham, J.P.; Price, L.B.; Silbergeld, E.K. Arsenic: A roadblock to potential animal waste management solutions. Environ. Health Perspect. 2005, 113, 1123-1124.

3. Sharpe, R.R.; Schomberg, H.H.; Harper, L.A.; Endale, D.M.; Jenkins, M.B.; Franzluebbers, A.J. Ammonia volatilization from surface-applied poultry litter under conservation tillage management practices. J. Environ. Qual. 2004, 33, 1183-1188. 
4. Gupta, G.; Charles, S. Trace elements in soils fertilized with poultry litter. Poult. Sci. 1999, 78, 1695-1698.

5. Kingery, W.L.; Wood, C.W.; Delaney, D.P.; Williams, J.C.; Mullins, G.L. Impact of long-term land application of broiler litter on environmentally related soil properties. J. Environ. Qual. 1994, 23, 139-147.

6. Moore, P.A., Jr.; Daniel, T.C.; Gilmour, J.T.; Shreve, B.R.; Edwards D.R.; Wood, B.H. Decreasing metal runoff from poultry litter with aluminum sulfate. J. Environ. Qual. 1998, 27, 92-99.

7. Toor, G.S.; Haggard, B.E.; Donoghue, A.M. Water extractable trace elements in poultry litters and granulated products. J. Appl. Poult. Res. 2007, 16, 351-360.

8. van der Watt, H.V.H.; Sumner, M.E.; Cabrera, M.L. Bioavailability of copper, manganese, and zinc in poultry litter. J. Environ. Qual. 1994, 23, 43-49.

9. Codling, E.E.; Chaney, R.L.; Mulchi, C.L. Effects of broiler litter management practices on phosphorus, copper, zinc, manganese, and arsenic concentrations in Maryland coastal plain soils. Commun. Soil Sci. Plant Anal. 2008, 39, 1193-1205.

10. Miller, D.M.; Miller, W.P. Handbook of Soil Science; Sumner, M.E., Ed.; CRC Press: Boca Raton, FL, USA, 2000; pp. G217-241.

11. United States Environmental Protection Agency (USEPA). Standards for the use or disposal of sewage sludge, Final Rules. 40 CFR Part 503. Fed. Regist. 1993, 58, 9387-9404.

12. Wenzel, W.W.; Kirchbaumer, N.; Prohaska, T.; Stingeder, G.; Lombi, E.; Adriano, D.C. Arsenic fractionation in soils using an improved sequential extraction procedure. Anal. Chim. Acta. 2001, 436, 309-323.

13. Lombi, E.; Sletten, R.S.; Wenzel, W.W. Sequentially extracted arsenic from different size fractions of contaminated soils. Water Air Soil Pollut. 2000, 124, 319-332.

14. Onken, B.M.; Adriano, D.C. Arsenic availability in soil with time under saturated and subsaturated conditions. Soil Sci. Soc. Am. J. 1997, 61, 746-752.

15. Sarkar, D.; Makris, K.C.; Parra-Noonan, M.T.; Datta, R. Effect of soil properties on arsenic fractionation and bioaccessibility in cattle and sheep dipping vat sites. Environ. Int. 2007, 33, 164-169.

16. Shiowatana, J.; McLaren, R.G.; Chanmekha, N.; Samphao, A. Fractionation of arsenic in soil by a continuous-flow sequential extraction method. J. Environ. Qual. 2001, 30, 1940-1949.

17. Han, F.X.; Kingery, W.L.; Selim, H.M.; Gerard, P.D.; Cox, M.S.; Oldham, J.L. Arsenic solubility and distribution in poultry waste and long-term amended soil. Sci. Total Environ. 2004, 320, 51-61.

18. Miller, D.M.; Miller, W.P. A micro-pipette method for soil mechanical analysis. Commun. Soil Sci. Plant Anal. 1987, 18, 1-15.

19. Loeppert, R.H.; Inskeep, W.P. Methods of Soil Analysis (Part 3); Sparks, D.L., Ed.; Soil Science Society of America: Madison, WI, USA, 1996; pp. 645-650. 
20. Jackson, B.P.; Bertsch, P.M.; Cabrera, M.L.; Camberato, J.J.; Seaman, J.C.; Wood, C.W. Trace element speciation in poultry litter. J. Environ. Qual. 2003, 32, 535-540.

21. US Environmental Protection Agency. Method 3050B: Acid Digestion of Sediments, Sludges, and Soils. In Test Methods for Evaluating Solid Waste, Physical/Chemical Methods, 3rd ed.; Publ. SW-846, Rev 6; US Environmental Protection Agency: Washington, DC, USA, 2007. Available online: http://www.epa.gov/epawaste/hazard/testmethods/sw846/pdfs/3050b.pdf (accessed on 1 May 2011).

22. US Environmental Protection Agency. Method 3051A: Microwave-assisted Acid Digestion of Sediments, Soils, and Oils. In Test Methods for Evaluating Solid Waste, Physical/Chemical Methods, 3rd ed.; Publ. SW-846, Rev 6.; US Environmental Protection Agency: Washington, DC, USA, 2007. Available online: http://www.epa.gov/epawaste/hazard/testmethods/sw846/pdfs/ 3051a.pdf (accessed on 1 May 2011).

23. Reed, S.T.; Martens, D.C. Copper and zinc. In Methods of Soil Analysis (Part 3); Sparks, D.L., Ed.; Soil Science Society of America: Madison, WI, USA, 1996; pp. 703-722.

24. SAS Institute Inc. The SAS system for windows, Version 9.2; SAS Institute Inc: Cary, NC, USA, 2008.

25. Sarkar, D.; Datta, R.; Sharma, S. Fate and bioavailability of arsenic in organo-arsenical pesticide-applied soils. Part-I: Incubation study. Chemosphere 2005, 60, 188-195.

26. Rutherford, D.W.; Bednar, A.J.; Garbarino, J.R.; Needham, R.; Staver, K.W.; Wershaw, R.L. Environmental fate of roxarsone in poultry litter. Part II. Mobility of arsenic in soils amended with poultry litter. J. Environ. Sci. Technol. 2003, 37, 1515-1520.

27. Han, F.X.; Kingery, W.L.; Selim, H.M.; Gerard, P.D. Accumulation of heavy metals in a long-term poultry waste-amended soil. Soil Sci. 2000, 165, 260-268.

28. Brock, E.H.; Ketterings, Q.M.; McBride, M. Copper and Zinc accumulation in poultry and dairy manure-amended fields. Soil Sci. 2006, 171, 388-399.

29. Pederson, G.A.; Brink, G.E.; Fairbrother, T.E. Nutrient uptake in plant parts of sixteen forages fertilized with poultry litter: Nitrogen, Phosphorus, Potassium, Copper, and Zinc. Agron. J. 2002, 94, 895-904.

30. Brye, K.R.; Pirani, A.L. Metal uptake by tall fescue (Festuca arundinacea) as affected by poultry litter application. Grass Forage Sci. 2006, 61, 192-199.

31. Macnicol, R.; Beckett, P. Critical tissue concentrations of potentially toxic elements. Plant Soil 1985, 85, 107-129.

32. Mineral Tolerance of Domestic Animals, National Academy of Sciences, 2nd ed.; National Research Council (NRC): Washington, DC, USA, 2005.

33. Mineral Tolerance of Domestic Animals. National Academy of Sciences; National Research Council (NRC): Washington, DC, USA, 1980.

34. Soon, Y.K.; Bates, T.E.; Moyer, J.R. Land application of chemically treated sewage sludge: III. Effects on soil and plant heavy metal content. J. Environ. Qual. 1980, 9, 497-504. 
35. Warman, P.R.; Termeer, W.C. Evaluation of sewage sludge, septic waste and sludge compost applications to corn and forage: $\mathrm{Ca}, \mathrm{Mg}, \mathrm{S}, \mathrm{Fe}, \mathrm{Mn}, \mathrm{Cu}, \mathrm{Zn}$ and $\mathrm{B}$ content of crops and soils. Bioresource Technol. 2005, 96, 1029-1038.

36. Zhou, D.M.; Hao, X.Z.; Wang, Y.J.; Dong, Y.H.; Cang, L. Copper and Zn uptake by radish and pakchoi as affected by application of livestock and poultry manures. Chemosphere 2005, 59, 167-175.

(C) 2011 by the authors; licensee MDPI, Basel, Switzerland. This article is an open access article distributed under the terms and conditions of the Creative Commons Attribution license (http://creativecommons.org/licenses/by/3.0/). 